\title{
Effects of the novel formin INF1 on ciliogenesis
}

\author{
S Copeland, C Tenneson, W Kulacz, J Copeland ${ }^{*}$ \\ From Cilia 2014 - Second International Conference \\ Paris, France. 18-21 November 2014
}

\section{Objective}

INF1 is a novel member of the formin family of cytoskeletal regulatory proteins. We previously identified a connection between INF1 expression and microtubule acetylation and more recently have found that INF1 expression induces Golgi dispersion. Given the dependence of ciliogenesis on microtubule acetylation and Golgi-dependent trafficking we wished to determine the effects of INF1 expression on cilia formation.

\section{Methods}

Transient transfection was used to express a series of INF1 derivative in NIH 3T3 cells and the effects on cilia formation, cilia length and Golgi dispersion were monitored by immunofluorescence. Anti-acetylated tubulin was used to visualize cilia and anti-Giantin was used to visualize Golgi morphology.

\section{Results}

INF1 expression inhibited ciliogenesis in the majority of NIH 3T3 fibroblasts, however, inhibition of ciliogenesis was not connected to INF1-induced Golgi dispersion. A minority of INF1-expressing cells did form cilia and these were greatly elongated, the longest exceeding $70 \mathrm{~mm}$. A series of INF1 deletion derivatives were used to show that both inhibition of cilia formation and the induction of cilia elongation were dependent upon both the FH2 and microtubule-binding domains of INF1.

\section{Conclusion}

The effects of INF1 expression on ciliogenesis were separate from its effects on Golgi-dispersion suggesting that Golgi untethering does not always inhibit ciliogenesis. The morphology of the elongated cilia formed in INF1 expressing cells is consistent with defects in dynein function.

\footnotetext{
Cellular and Molecular Medicine, University of Ottawa, Ottawa, Ontario,
} Canada

Submit your next manuscript to BioMed Central and take full advantage of:

- Convenient online submission

- Thorough peer review

- No space constraints or color figure charges

- Immediate publication on acceptance

- Inclusion in PubMed, CAS, Scopus and Google Scholar

- Research which is freely available for redistribution 